\title{
Delville Wood : Eighty years July 1916 - July 1996
}

\author{
G. GENIS \\ DOCUMENTATION SERVICE DIRECTORATE, SANDF
}

\begin{abstract}
Hierdie is die verhaal van 1 Suid-Afrikaanse Infanteriebrigade wat in die loop van die Somme-offensief (1 Julie tot 18 November 1916) gedurende die Eerste Wêreldoorlog aan die slag te Delvillebos deelgeneem het. Die Brigade was deel van die Skotse 9de Divisie wat Longueval en Delvillebos op die wesfront in Frankryk op 14 Julie 1916 aangeval het. Op 15 Julie 1916 het die Suid-Afrikaners Delvillebos ingeneem en die Duitsers verdryf. Vanaf 15 Julie tot 20 Julie 1916 het die Duitsers teruggeslaan en 1 Suid-Afrikaanse Brigade (wat uit vier infanterieregimente bestaan het) is in die bos aangeval. Die SuidAfrikaners het vir ses dae dapper geveg teen die intense Duitse offensief wat met hewige artillerievuur gepaard gegaan het. Om 18:00 op 20 Julie 1916 is die laaste groepie SuidAfrikaners in die bos onder aanvoering van luitenant-kolonel Edward Thackeray deur die Norfolk Regiment afgelos. Die Suid-Afrikaners het geweldige verliese gely in hul poging om die bos te behou en het die agting van vriend en vyand verkry. Nie net die veldslag nie maar ook die daaglikse ondervindinge van die Suid-Afrikaanse soldaat word bespreek. Hierdie artikel handel dus ook oor die sosiale geskiedenis van die soldaat tydens die slag van Delvillebos en temas soos militêre uitrustings, rantsoene, daaglikse verpligtinge en die lewensomstandighede van die soldaat word bespreek.
\end{abstract}

\section{Introduction}

This year heralds the 80th anniversary of the Battle for Delville Wood which was fought from 14 July 1916 to 20 July 1916 . This battle is one of the bloodiest chapters in the annals of South Africa's military history. Although much has been written on the battle the author will describe the less documented daily experiences of the common soldier as well.

It is striking that so much attention was paid to the commemoration of the battles of the Second World War while the 75th anniversary of the end of the First World War in 1993 passed almost unnoticed. During this July let us make sure not to forget the sacrifices made by all South Africans in France and on other fronts during the Great War.

The First World War commenced on 4 August 1914 when Germany invaded Belgium. Britain was drawn into the war because she had signed a treaty with Belgium in 1839 in which she guaranteed the latter's sovereignty. Thus in 1914 Britain had to defend Belgium's integrity and declared war on Germany. Germany had already declared war on Russia and France on 1 August 1914 and 3 August 1914 respectively. Britain was bound to France by the entente cordiale of 1904 which cleared up coIonial differences between the two countries. Although this was not a military alliance the understanding between Britain and France grew and by

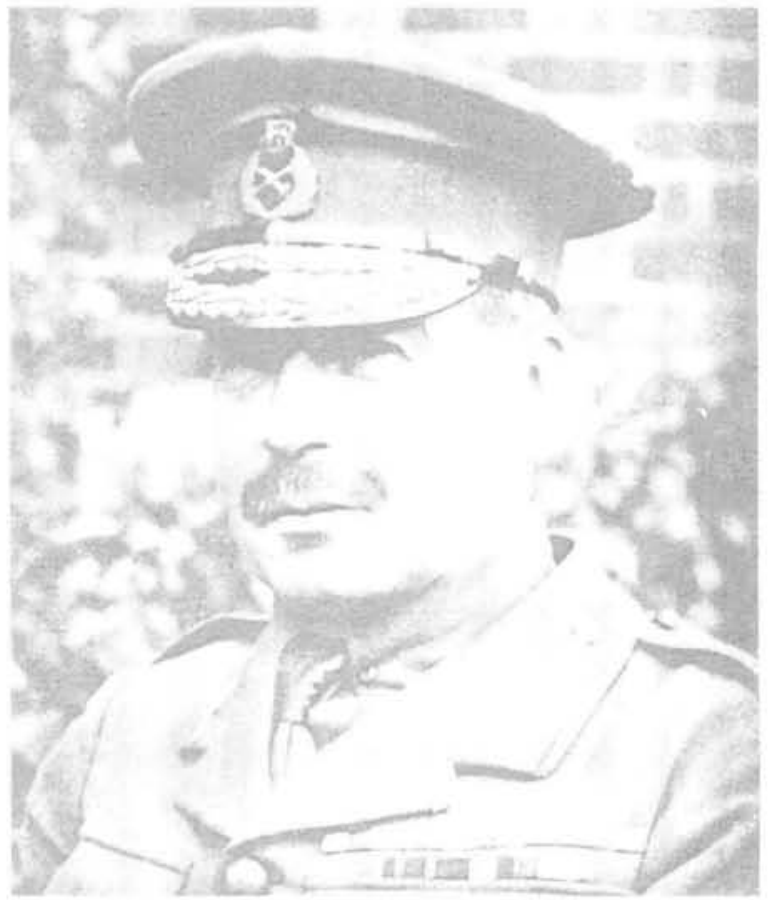

Brigadier General Henry Timson Lukin. The commander of 1 South African Infantry Brigade

SANDF Archives, 791-467

1914 became more anti-German. In 1907 Britain and Russia had settled their colonial differences. The Union of South Africa as part of the British Empire, supported Britain's effort and defeated the Germans in German South-West Africa (the present day Namibia). In July 1915 the Union's of- 


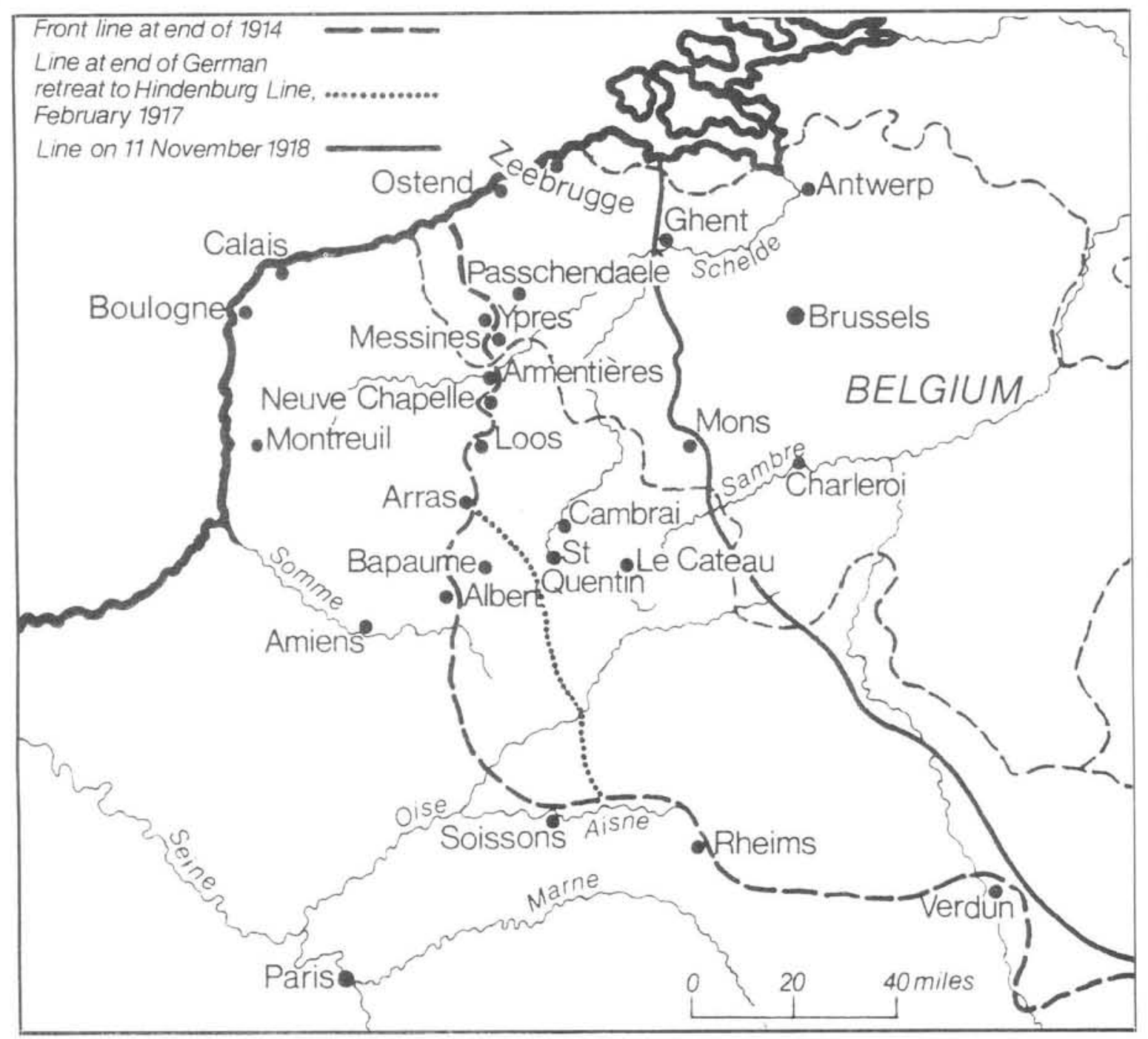

The Western Front

M. Brown. The Imperial War Museum Book of the First World War, London, Sidgwick \& Jackson, 1993, p. 285

fer to raise volunteer forces for service in German East-Africa and France was accepted by the British Government. The expeditionary force which was formed for service in France and Libya was designated 1 South African Infantry Brigade and was commanded by Brigadier General Henry Timson Lukin. Lukin had a distinguished military career and fought in many important campaigns in South Africa's history, such as the Zulu War (1879), the AngloBoer War (1899-1902, also known as the South African War) and in the German South-West Africa campaign (1915-1916). 'In 1912 Lukin was promoted to Inspector General of the Union Defence Force with the rank of Brigadier General.

The South African Brigade consisted of four regiments: 1 South African Infantry (SAl) Regiment (Cape of Good Hope Regiment), 2 South African Infantry (SAI) Regiment (Orange Free State and
Natal Regiment), 3 South African Infantry (SAI) Regiment (Transvaal and Rhodesia Regiment) and 4 South African Infantry (SAI) Regiment (South African Scottish Regiment). 64 Field Company and 28 Machine-Gun Company were attached to the Brigade. The Brigade numbered 160 officers and 5648 other ranks. ${ }^{2}$ About 15 per cent of the original Brigade consisted of Afrikaans speaking South Africans (Afrikaners or Boers). This percentage rose to 30 per cent before the end of the war. The Brigade was an infantry brigade and traditionally the Afrikaners were not infantrymen but horsemen. Many other Afrikaners fought with distinction as horsemen in the German South-West Africa (19151916) and German East-Africa campaigns (19141918) against the enemy. It is surprising that so many Afrikaners volunteered to join the Union Defence Force in the First World War as there was still a lot of ill feeling between English and Afrikaans

M. Brown, The Imperial War Museum Book of the Western Front, p. 3: J. Buchan, The History of the South African Forces in France, pp.15,19.

2 J. Ewing, The History of the 9th (Scottish) Division. 1914-1919, p.96: J. Buchan, South African Forces in France, p. 16: R. Cornwell, "Delville Wood: The South Africans in France, April-July 1916", Militaria 7(2), 1977, pp.2,3,8. 


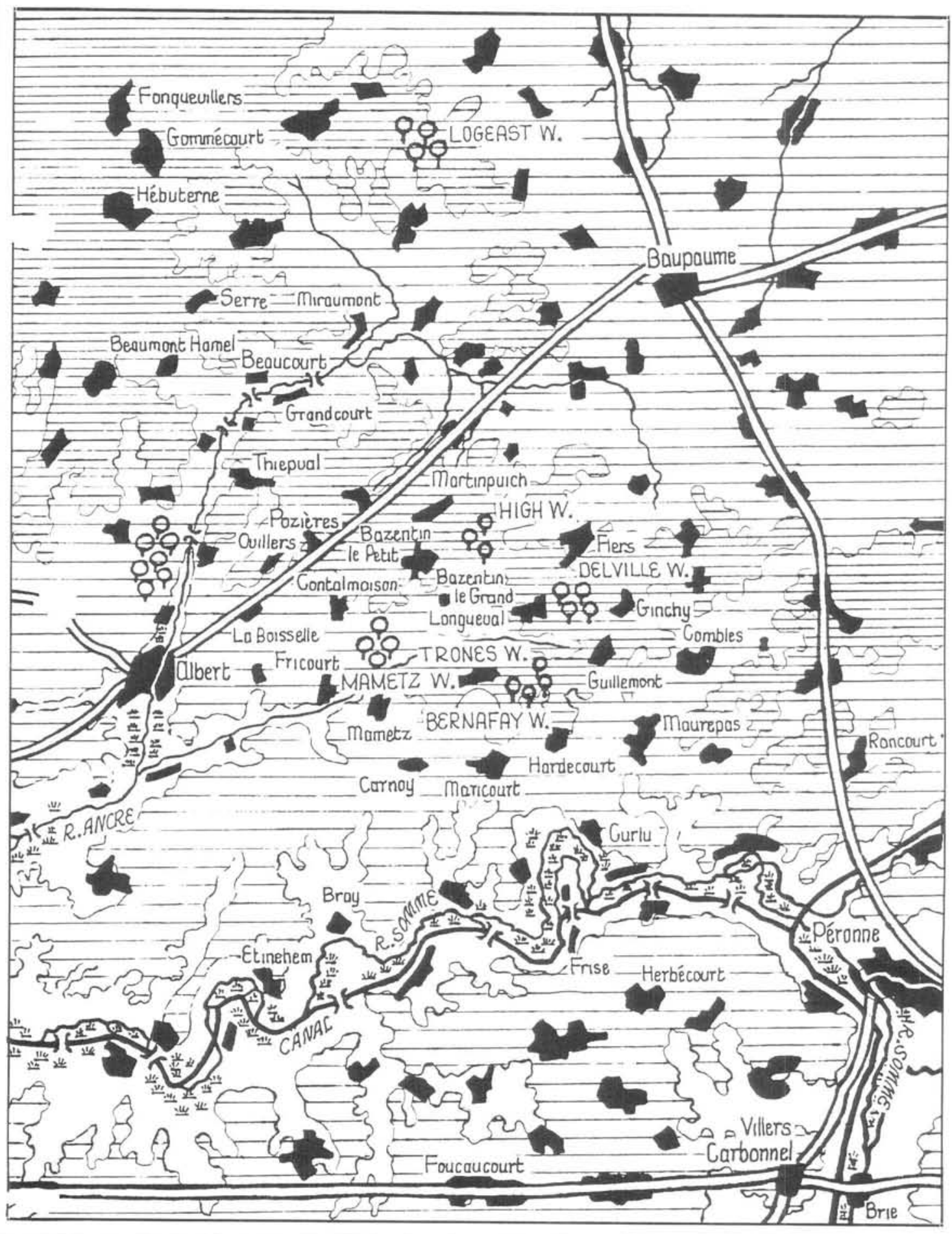

The Somme, 1916

R. Cornwell, "Delville Wood: The South Africans in France, April-July 1916", Militaria 7(2), 1977, p.12

speaking South Africans. This was due to the Anglo-Boer War during which the two Afrikaner Republics, the South African Republic and the Orange Free State, were annexed by Britain. Animosity was also rife between Afrikaners. During the Rebellion of 1914-1915 a group of Afrikaners had hoped to re-establish the former Afrikaner Republics. Pro-Union Afrikaners supported Gen- eral Louis Botha, the premier of the Union of South Africa, in his efforts to quell the Rebellion. Louis Botha and General J.C. Smuts, the Minister of Defence, tried to reconcile Bcer and Briton after the establishment of the Union of South Africa on 31 May 1910. Many Afrikaners also felt racially and emotionally affiliated to the Germans as they were descended from German forefathers. ${ }^{3}$ 


\section{Fighting around Delville Wood}

The South African Brigade to France reached Marseilles on 19 April 1916 after their successful campaign in Western Egypt against the Senussi. Headquarters was established at Bailleul and the Brigade was trained in trench warfare. On 4 June the Brigade moved to the Steenbecque and Morbecque area and ten days later to the Somme. Together with 26 and 27 Brigades, two Scottish Brigades, the South African Brigade formed part of the Ninth
(Scottish) Division under the command of Major General W.T. Furse. This Division formed part of XIII Corps under the command of Lieutenant General Walter Congreve of the Fourth Army. The Ninth Division established its battle headquarters at Grovetown. ${ }^{4}$

When the Battle of the Somme commenced on 1 July 1916, the South Africans as part of XIII Corps were stationed on the right wing of the British offence north of the river Somme, south of the Albert-

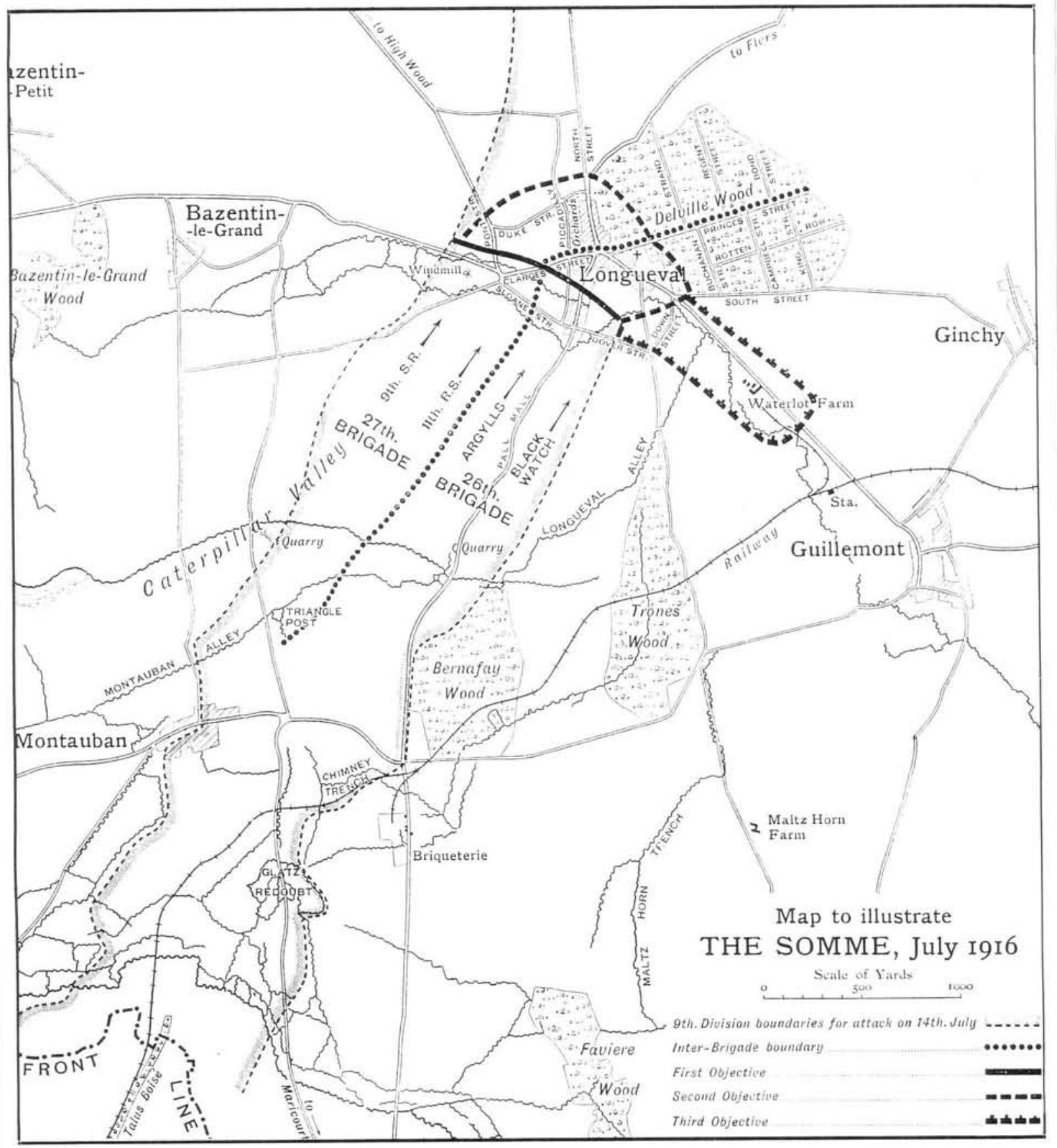

Delville Wood

J. Ewing, The History fo the 9th (Scottish) Division, 1914-1919, London, John Murray, 1921, p. 437

P.K.A. Digby, Pyramids and Poppies: The 1st SA Infantry Brigade in Libya, France and Flanders 1915-1919, p.112; R. Cornwell, "Delville Wood", Militaria 7(2), 1977, pp.8,13,15; J. Ewing, The 9th (Scottish) Division, p.96; J. Buchan, South African Forces in France, pp.23-47,51. 
Baupaume road. The main function of XIII Corps was to capture the ridge running from Waterlot Farm (south of Delville Wood) to Bazentin-le-Grand, to conquer Montauban and surrounding trenches, to secure Montauban Alley and to reach Bernafay and Trônes Woods. ${ }^{5}$

During this first offensive of the Battle of the Somme the Ninth Division was held in reserve. On 2 July 1916 the South African Brigade moved from Grovetown (near Bray) to Billon Valley and during the next day relieved 27 Brigade in Trigger Wood, Billon Wood and Copse Valley. During 5 July, 21 and 89 Brigades (30 Division) in the Glatz Sector were relieved by 1 and 4 South African Infantry (SAI) Regiments and 2 SAI Regiment moved to Talus Boise. 3 SAl Regiment moved to the north-west of Maricourt. From 5 July to 7 July the South African Brigade was subjected to artillery fire and suffered several casualties. During the following two days a section of 2 SAI Regiment relieved 12 Royal Scots and 6 King's Own Scottish Borderers (KOSB) of 27 Brigade in Bernafay Wood and 3 SAI Regiment occupied Glatz Redoubt.

On 9 July A and C Companies (Coys) of 4 SAI Regiment fought in Trônes Wood and had to fall back to Glatz Redoubt the following day. $B$ and $D$ Coys of this regiment relieved 2 SAl Regiment in Bernafay Wood. On 13 July the South Africans in Bernafay Wood were relieved and the whole Brigade assembled at Talus Boise. The South African Brigade was the reserve Brigade of the Ninth Division during the attack on Longueval Village which was to commence on 14 July $1916 .^{6}$

The attack in which the South Africans were going to take part was of great importance to the plans of General Sir Douglas Haig, Commander-in-Chief of the British forces on the Western Front. Haig wanted to conquer High Wood to the north of Longueval and Delville Wood and capture Ginchy and Guillemont respectively to the south-east and south of Delville Wood and Longueval. The conquest of Longueval and Delville Wood (which were strategically seen as a unit), which were situated near high ground, would make the attack on Haig's objectives easier. ' High ground was of strategic importance because it facilitated observation on enemy positions.
The fight was not going to be easy as XIII Corps had to take on the experienced 16 Bavarian Regiment and 6 Bavarian Reserve Regiment of the Tenth Bavarian Division. ${ }^{8}$

\section{Fighting in Delville Wood}

Before the assualt on Delville Wood started LanceCorporal Ernest Solomon of 3 SAl Regiment described the scene: "Delville Wood covered a large area; its trees, closely set, towered to a great height, where the leafy branches intermingled and formed a screen so thick that, in parts, the view of sky was almost obscured. Here and there was a clearing. here and there a narrow road, here and there a footpath; but for the most part nothing but trees and thick undergrowth". ${ }^{9}$ At the end of the battle this idyllic setting would be utterly destroyed by shells, rifle and machine-gun fire and gas attacks.

On 14 July 1916 Brigadier General Lukin received the order from General Furse to occupy the perimeter of Delville Wood the moment Longueval was captured by 26 and 27 Brigades (Delville Wood borders the village of Longueval on the east). General Lukin then issued Operation Order No 48 to the South African Infantry Brigade to attack Delville Wood from the west. 3 SAI Regiment was instructed to attack the area north of Princes Street and 2 SAI Regiment the area to the south of this street respectively. 4 SAI Regiment was to be held in reserve in trenches south of Montauban and 1 SAI Regiment was instructed to help 27 Brigade in its attack on Longueval and to penetrate Delville Wood. The attack was to be preceeded by an artillery bombardment. ${ }^{10}$

On 14 July 1 SAI Regiment under Lieutenant Colonel F.S. Dawson occupied Montauban Alley and marched to the area north of Princes and west of Strand Streets. B Coy (the left flank) reached a trench west of the objective and A Coy (the right flank) occupied a position situated to the east of the position held by B Coy. C and D Coys supported $\mathrm{A}$ and $\mathrm{B}$ Coys respectively. Because the regiment was subjected to heavy machine-gun fire from the west, north-east and north casualties amounted to 4 officers and approximately 50 other ranks. 1 SAI Regiment was ordered to capture the I. Uys, Rollcall: The Delville Wood Story, p. 21; R. Cornwell, "Delville Wood", Militaria 7(2), 1977, pp. 13,14,15-17; J. Ewing. The 9th
(Scottish) Division, p.102. R. Cornwell, "Delville Wood". Militaria 7(2), 1977, pp.21,22; J. Buchan, South African Forces in France, pp.53-54,55: P.K.A. Digby,
Pyramids and Poppies, pp.114-115,119; I. Uys, Rollcall, p.32.

J. Ewing, The 9th (Scottish) Division, p.102.

J. Ewing, The 9th (Scottish) Division, p.102.

E. Solomon, Potchefstroom to Delville Wood (with the 3rd South African Infantry): Together with some experiences as a Prisoner of War in Germany, p.61.

10. Documentation Service Directorate of the SANDF (hereafter SANDF Archives): Archive Group: World War One Diaries and Appendices (hereafter WOI DA). Box 5, War Diary, South African Infantry Brigade Headquarters July 1916 , Operations on the Somme; Despatch No III by Brigadier General H.T. Lukin Commanding 1st S.A. Infantry Brigade. Frevillers. dated 14 August 1916; Ibid., 1st South African Brigade Operation Order No 48, In the Field, 14 July 1916, p.2; I. Uys, Rollcall, pp.34-38. 
machine-guns which were frustrating the advance."

4 SAI Regiment (led by Major D.M. MacLeod after Lieutenant Colonel F.A. Jones was killed on 11 July) moved on 14 July by sunken road from Bernafay Wood to a position near Longueval Village. Two platoons each from B and C Coys assisted $5 \mathrm{Ca}$ meron Highlanders (26 Brigade) to occupy Waterlot Farm to the south of Delville Wood. A and D Coys were ordered to advance to Delville Wood. ${ }^{12}$

Early on 15 July Operation Order No 48 was changed. It was decided that the attack of 2 and 3 SAI Regiments would now commence from the south-west. The reason for this change in plan was that 26 and 27 Brigades had not succeeded in capturing the northern part of Longueval and had suffered heavy losses in the process. The South Africans would therefore have been exposed to German artillery and rifle fire if they had attacked from the west. $^{13}$

The command by the General Officer Commanding (General Lukin) was confirmed to 3 SAI Regiment by Order BM 45. This Regiment was ordered to lead the attack with 2 SAl Regiment in support. 3 SAI Regiment was led by Lieutenant Colonel E.F. Thackeray and 2 SAI Regiment by Lieutenant Colonel W.E.C. Tanner respectively. At 04:00 the two Regiments reached the support trench east of Longueval. At 09:00, 3 SAl Regiment occupied the area between Princes and South Streets. A and $B$ Coys held the eastern and north-eastern ends of 3 SAI Regiment's sector. C Coy dug themselves in just north of South Street, D Coy on Princes Street and advanced north-eastwards until they reached a position approximately halfway between Princes Street and the northern edge of the wood.

2 SAI Regiment occupied the area north of Princes Street. They held an area stretching from the northeastern end of the wood, westwards to a point not further west than Strand Street. southwards stretching parallel with Strand Street to where this street crossed Buchanan Street. During the day B and D Coys (3 SAI Regiment) captured three officers and
135 men. The Germans' strongpoints were situated in the area to the south-east, east and northeast of Delville Wood (the area stretching from Waterlot Farm and Ginchy northwards to Flers) The Headquarters of 3 and 2 SAI Regiments was situated on Buchanan Street. ${ }^{14}$

All four companies of 4 SAI Regiment were shelled on 15 July. $B$ and $C$ Coys were situated in the communication trenches near the sunken road to the south-west of Delville Wood and A and D Coys were situated in the north-eastern corner of Delville Wood where they used hastily dug trenches and craters as cover. 1 SAI Regiment destroyed a German machine-gun which was causing problems in North Street (North Street ran in a northernly direction through the orchards west of Delville Wood and north east of Longueval). ${ }^{15}$

The South Africans had to deal with various problems on 15 july. The SAI Brigade was subjected to enemy bombardments and fire and suffered fatigue. Sniperfire was also a constant danger. Because of the enemy fire many casualties occured in the process of wiring the perimeter of the wood with barbed wire. It was essential for the South Africans to dig trenches for protection and cover. The digging was hampered by roots and strewn tree trunks which had been blown off by shellfire and thus it took longer than usual to dig a trench. This was one of the reasons why so many casualties occured. 3 SAI Regiment suffered 140 casualties and 2 SAI Regiment 64. ${ }^{16}$

On 16 July 1916 the South Africans again came under heavy German fire. Enemy snipers who remained to the rear of 2 SAI Regiment, were responsible for considerable casualties and hampered the transport of ammunition and rations. In the eastern and north-eastern part of the wood the troops were reinforced by a Coy of 4 SAI Regiment. One Coy of 2 SAI Regiment moved to South Street. C and D Coys of 1 SAl Regiment were in support of 2 SAI Regiment. At 10:00 two Coys of 4 SAI Regiment under Major D.R. Hunt and A Coy of 1 SAl Regiment under Major Edward Burges, at-

SANDF Archives: WOI DA, Box 5, War Diary. 1st South African Infantry Regiment July 1916, Operations on the Somme; SANDF Archives: WOI DA, Box 1. War Diary, 1 BN SA Infantry (spare). July 1916. 1st Battalion. South African Infantry, dated 1 August 1916, pp.1-3.

12 SANDF Archives: WOI DA, Box 5. War Diary, 4th South African Regiment July 1916. Operations on the Somme, dated 31 July 1916, pp.3-4.

13 SANDF Archives: WOI DA, Box 5, War Diary, South African Infantry Brigade Headquarters July 1916, Operations on the Somme: Despatch No III by Brigadier General H.T. Lukin Commanding 1st S. A. Infantry Brigade, Frevillers. dated 14 August 1916 p.3 P.K.A. Digby, Pyramids and Poppies, pp.123-124; I. Uys, Rollcall, p.38.

14 SANDF Archives: WOI DA, Box 5, War Diary, 3rd South African Infantry Regiment July 1916, Operations on the Somme. (Attached: Appendices 143-157), pp.26-27; Ibid.. BM45 dated 14 July 1916. Appendix 154.

15 SANDF Archives: WOI DA, Box 5, War Diary, $1 \mathrm{st}$ South African Infantry Regiment July 1916, Operations on the Somme, dated 1 August 1916; SANDF Archives: WOI DA. Box 3. War Diary \& Appendices, 1 Regt SAl July 1916. 1st Battalion. South African Infantry, dated 1 August 1916, p.3

16 SANDF Archives: WOI DA, Box 5, War Diary, South African Infantry Brigade Headquarters July 1916, Operations on the Somme: Despatch No. III by Brigadier General H.T. Lukin Commanding 1st S.A. Infantry Brigade, Frevillers, dated 14 August 1916, pp.4-5; SANDF Archives: WOI DA, Box 5, War Diary, 2nd South African Infantry Regiment July 1916, Operations on the Somme, p.2. 
tacked the north-western part of Delville Wood and the northern sector of Longueval. German machinegun fire all but wiped out these advancing troops and made further advance impossible. One Coy of 1 SAI Regiment was pinned down along Strand Street, the two Coys of 4 SAI Regiment held a trench north of Princes and east of Strand Streets and 2 SAI Regiment lent support in the direction of Strand Street. At the end of 16 July no further progress had been made. ${ }^{17}$

During 17 July B Coy of 1 SAI Regiment was relieved by the KOSB's and fell back to Longueval. Lieutenant Colonel Tanner, the commanding officer in the wood was wounded and was succeeded by Lieutenant Colonel Thackeray. 3 SAI Regiment also suffered casualties and all the officers of $C$ Coy 3 SAl in the south-eastern sector of the wood fell in battle. 2 SAI Regiment, however, dug themselves further in. During the day the Germans were reinforced from Flers and Ginchy and launched two attacks. They attacked from the north-west but were forced to withdraw due to heavy losses. A second attack on the northern, north-eastern, eastern and southern perimeters was also repulsed. At daybreak they had attacked A and D Coys of 4 SAI Regiment in the north-eastern sector of the wood but were beaten back after they had reached the parapets. A and D Coys were constantly attacked and bombarded and B and C Coys (4 SAI Regiment) were embattled in their trenches. The South Africans suffered heavy losses and more casualties were inflicted by the German snipers. ${ }^{18}$

"It was as if night for ever refused to give way to day. A drizzling rain was falling in an atmosphere unstirred by a breath of wind. Smoke and gases clung to and polluted the air, making a canopy impervious to light. What a contrast was this Tuesday morning to the morning of the previous Saturday, when we first entered what was then a beautiful sylvan scene, but now everywhere a dreary waste! ". ${ }^{19}$ This is Private John A. Lawson's (3 SAl Regiment) impression of the situation in the wood on the morning of Tuesday 18 July 1916.

On this day the situation in the wood became desperate. The enemy continued their bombardment of the wood. During 18 July 1916 approximately 20000 shells fell in the wood - an area covering less than a square mile. C and D Coys of $1 \mathrm{SAI}$
Regiment and A and D Coys of 4 SAl Regiment suffered heavily. At 07:00 a section of C Coy 4 SAI Regiment was sent to assist Major Edward Burges (1 SAI Regiment) in Delville Wood. Later that afternoon all the available men of 1 and 4 SAl Regiment were ordered by Lieutenant Colonel Dawson (1 SAl Regiment) to reinforce C and D Coys of 1 SAl Regiment under Major Edward Burges.

Major Burges supported A Coy of the Gordon Highlanders in an attack on the orchard north-west of the wood and in the north-western sector of the wood. This attack failed and Major Burges was killed. This exposed the left flank of 1 and 2 SAI Regiments and the Germans penetrated to the rear of the South Africans. The few South Africans fighting on the perimeter of the wood were either killed or wounded. The troops of 1 and 4 SAI Regiments who were sent to relieve the soldiers under Major Burges fell back to the trenches south-west of Longueval and to Longueval itself. 2 SAI Regiment had also fallen back from the perimeter. Meanwhile 3 SAI Regiment under Lieutenant Colonel Thackeray, who was holding out on Buchanan and Princes Streets, was also embattled. All its officers were casualties and only a small number of men remained.

After 21:00 in the evening the Light Trench Mortar Battery (LTMB) under Lieutenant E.J. Phillips in excess of 100 men were sent to reinforce the beleaguered 3 SAl Regiment. Later approximately 25 men of 4 SAl Regiment were sent to reinforce the LTMB troops in the wood after Major Hunt had made contact with 3 SAI Regiment. Three large German forces attacked the remnants of the South African forces on Buchanan and Princes Streets from the north-west, north and north-east.

The Germans, consisting nine and a half battalions, were not able to drive the remaining South Africans back and were repulsed after suffering heavy losses. The South African strong point south of Buchanan Street was still being held by troops under Sergeant Major Thompson (2 SAI Regiment). At the close of 18 July the whole wood with the exception of the south-western corner and isolated pockets in the eastern and southern sectors was occupied by the Germans. During the evening the South Africans received the message that they were to be relieved by 26 Brigade. At midnight 26

17 SANDFArchives: WOI DA, Box 1, War Diary, 1 BN SA Infantry (Spare), July 1916, 1st Battalion, South African Infantry, dated 1 August 1916, pp.3-4; SANDF Archives: WOI DA, Box 5, War Diary, 3rd South African Infantry Regiment July 1916, Operations on the Somme, p.28; SANDF Archives: WOI DA, Box 5, War Diary, 2nd South African Infantry Regiment July 1916, Operations on the Somme, p.2.

18 SANDF Archives: WOI DA, Box 5, War Diary, 3rd South African Infantry Regiment July 1916, Operations on the Somme. (Attached: Appendices 143-157), pp.28-29; SANDF Archives: WOI DA, Box 1, War Diary, 1 BN SA Infantry (Spare), 1st Battalion, South African Infantry, dated 1 August 1916, p.5; SANDF Archives: WOI DA, Box 5, War Diary, 4th South African Regiment July 1916, Operations on the Somme, dated 31 July 1916, p.6; SANDF Archives: WOI DA. Box 5, War Diary, 2nd South African Infantry Regiment July 1916, Operations on the Somme, p.2.

J.A. Lawson, Memories of Delville Wood, South Africa's Great Battle, p.13. 


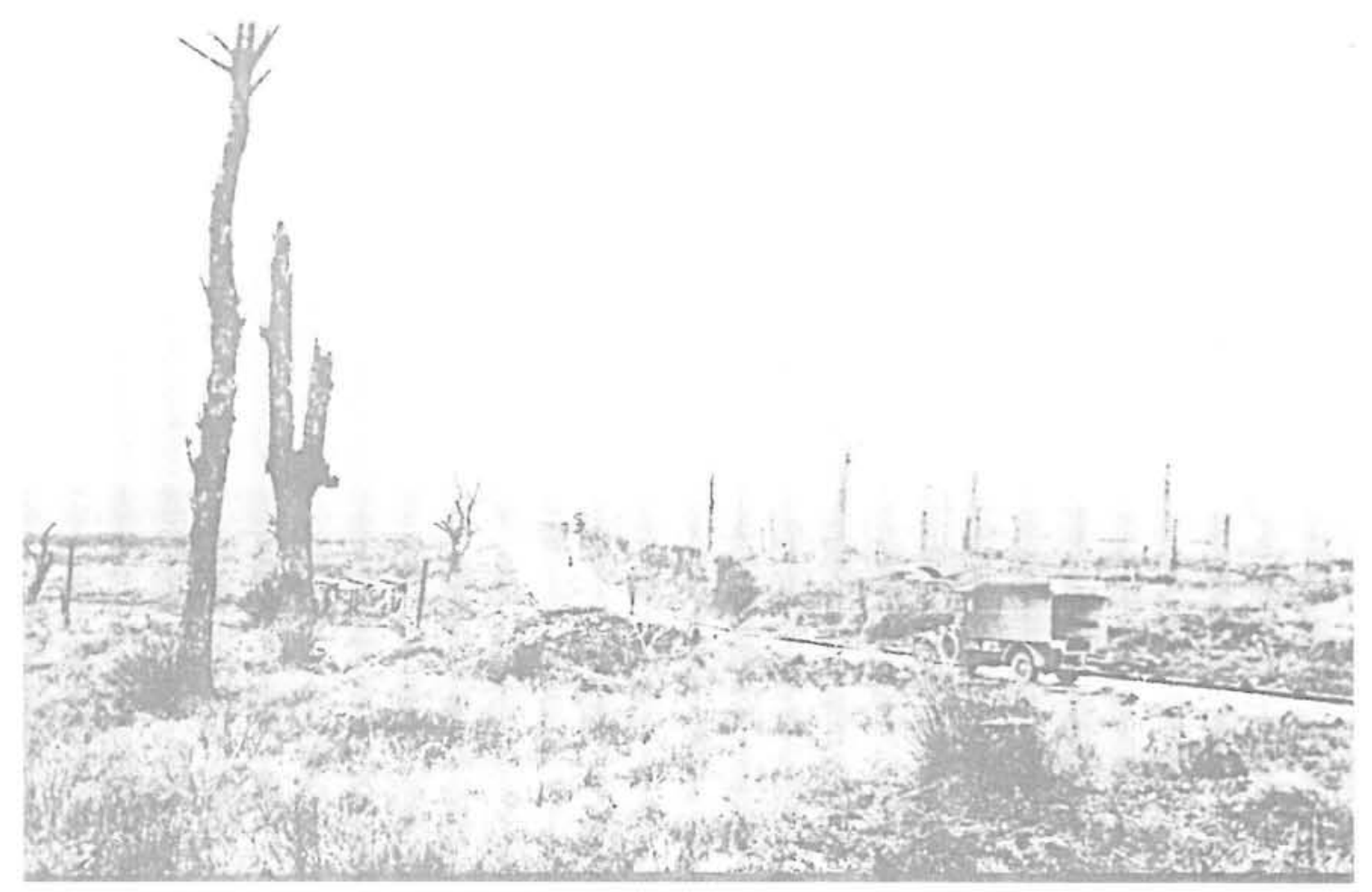

Delville Wood after the battle

SANDF Archives, $70-3634$

Brigade relieved the troops of 1 and 4 SAI Regiments in the south-east of Longueval. ${ }^{20}$

Most of the South Africans were relieved on 19 July 1916 with the exception of elements of troops of all four regiments under Thackeray and men of 3 SAI Regiment in the south-east who still held out against all odds. During the early morning 1,2 and 4 SAI Regiments withdrew to Talus Boise. Delville Wood was attacked by British Regiments: the Norfolk Regiment, the Berkshire Regiment and the Royal Welsh Fusiliers, but suffered heavy casualties in the process. The isolated pockets of men from 3 SAI Regiment in the eastern and southern sectors were overrun because they ran out of ammunition. Despite the German snipers, machine gunners and fierce bombardment (even from misguided British artillery fire which caused some casualties among the South Africans) the South Africans under Thackeray did not budge. Richard
Cornwell states that: "The casualties inflicted on the Germans on the 19th, followed by Thackeray's successful defence of Buchanan Street that night were achievements which may well have saved the entire flank of the British front." 21

After the South Africans under Thackeray had to endure another day (20 July 1916) of sniping and shelling they were relieved by the Suffolk Regiment during the evening of the same day. When they marched out of Delville Wood Thackeray's party was reduced to: nine other ranks of $1 \mathrm{SAl}$, one officer (Lieutenant Green) and 33 other ranks of $2 \mathrm{SAl}, 14$ other ranks of $3 \mathrm{SAl}, 25$ other ranks of $4 \mathrm{SAl}$ and one officer (Lieutenant Phillips) and 59 other ranks of the LTMB. 3 SAI Regiment lost 28 officers and 743 other ranks (killed, missing and wounded) and only one officer (Lieutenant Colonel Thackeray) and 104 men survived out of a total of 29 officers and 847 men. Lieutenant Colonel

20 SANDF Archives: WOI DA, Box 1, War Diary, 1 BN SA Infantry (Spare), July 1916, 1st Battalion, South African Infantry, dated 1 August 1916, pp.5-6; SANDF Archives: WOI DA, Box 5, War Diary, 4th South African Regiment July 1916, Operations on the Somme, dated 31 July 1916, pp.6-7; SANDF Archives: WOI DA, Box 5, War Diary, 2nd South African Infantry Regiment July 1916 , Operations on the Somme, p.2; SANDF Archives: WOI DA, Box 5, War Diary, 3rd South African Infantry Regiment July 1916. Operations on the Somme. (Attached: Appendices 143-157), pp.29-30; SANDF Archives: WOI DA, Box 5, War Diary, South African Infantry Brigade Headquarters July 1916, Operations on the Somme; Despatch No III by Brigadier General H.T. Lukin Commanding 1st S.A. Infantry Brigade, Frevillers, dated 14 August 1916, pp.9,10; R. Cornwell, "Delville Wood", Militaria 7(2), 1977, pp.53-54; P.K.A. Digby, Pyramids and Poppies, p. 132.

2. R. Cornwell, "Delville Wood", Militaria 7(2), 1977, pp.53-54; SANDF Archives: WOI DA, Box 5, War Diary, 3rd South African Infantry Regiment July 1916, Operations on the Somme. (Attached: Appendices 143-157), pp.30-31; Ibid.. War Diary, 2nd South African Infantry Regiment July 1916, Operations on the Somme, pp.2-3; SANDF Archives: WOI DA, Box 5, War Diary, South African Infantry Brigade Headquarters July 1916, Operations on the Somme; Despatch No III by Brigadier General H.T. Lukin Commanding 1st S.A. Infantry Brigade, Frevillers, dated 14 August 1916, p.9; Ibid., War Diary, 4th South African Regiment July 1916, Operations on the Somme, dated 31 July 1916, p.7; SANDF Archives: WOI DA, Box 3, War Diary \& Appendices, 1 Regt SAI July 1916, 1st Battalion, South African Infantry, dated 1 August 1916, p.7. 
Thackeray later reported the following in his summary of the battle in Delville Wood: "Every detachment of 3rd S.A.I. carried out instructions to hold on at all costs $+[\mathrm{sic}]$ not a single detachment retired from their positions, either in the perimeter of the wood or from the support trench".22

The numerically superior German troops had to wipe out the South Africans to retain the perimeter of Delville Wood. Between 14 and 20 July 1916 the South Africans suffered considerable casualties (killed, wounded, missing and captured). 1 SAI Regiment had eight officers and 213 men left of a total of 31 officers and 748 men, 4 SAI Regiment had seven officers and 183 men left out of a total of 27 officers and 672 men and 2 SAl Regiment had two officers and 185 men left out of a total of 26 officers and 669 men. The Machine-Gun Company had 17 other ranks left out of a total of 96 and lost all eight officers. ${ }^{23}$

The Ninth Division lost 314 officers and 7203 men from 1 to 20 July but the South African Brigade suffered more than the other two Brigades. Fighting in the wood continued until 8 September 1916 when the last Germans were driven out. This is an indication of how difficult it was to take and hold Delville Wood. ${ }^{24}$ After Delville Wood the war was not over for the South Africans. Three months after their ordeal at Delville Wood they fought at the Butte de Warlencourt and suffered more than 1100 casualties. After this the South Africans fought at various places including Arras, Fampoux. Ypres, Moslains, Gouzeancourt, Marrières Wood, Rancourt, The Battle of Lys, Messines Ridge, Wytschaete, Reumont and Le Cateau. When the ceasefire took effect on 11 November 1918 the Brigade held the eastern most position on the Western front. From April 1916 to November 1918 nearly 20000 South Africans took part in the campaign on the Western Front. Just 6000 of these were not casualties. On all fronts South Africa put more than 136000 troops in the field (the fourth most of all British Dominions and colonies, including India). Of these nearly 7000 were killed and more than 11000 wounded and captured. More than 107000 Blacks, Indians and Coloureds took part as labourers, transport drivers and wagon-leaders and of these more than 4000 were killed. ${ }^{25}$

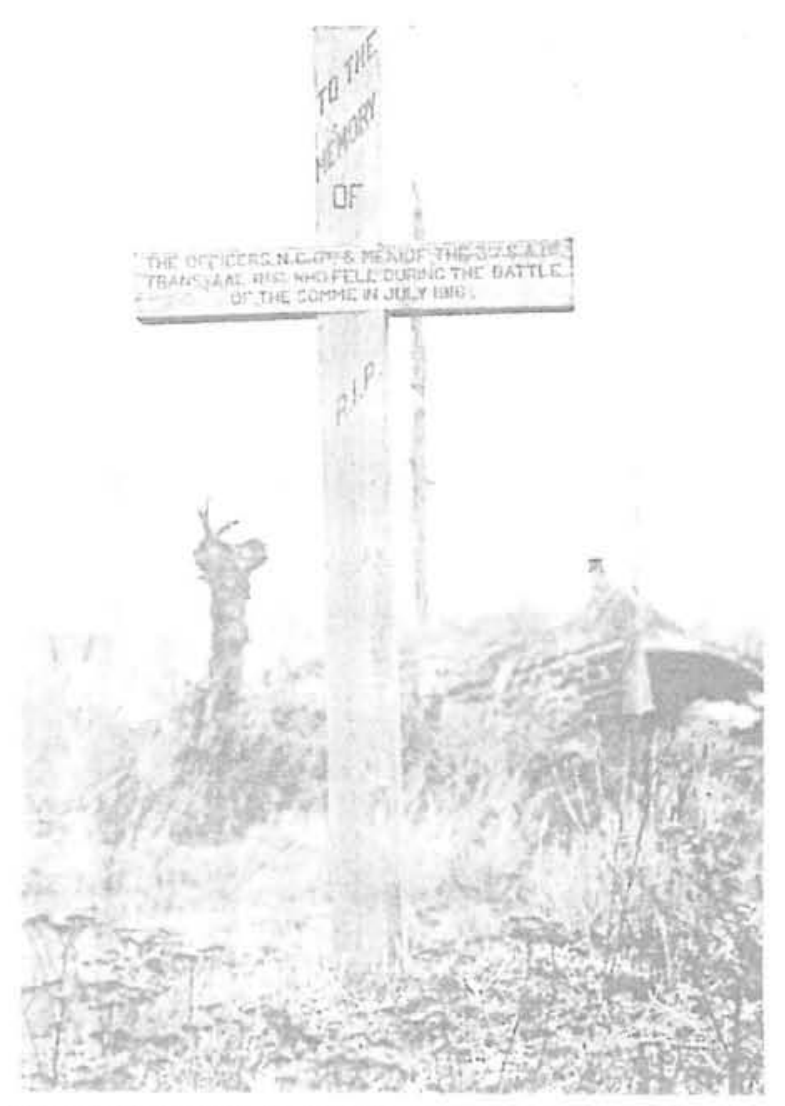

The cross commemorating the men of $3 \mathrm{SAl}$ Regiment who fell during the Battle of the Somme, July 1916

SANDF Archives, 761-743

\section{The Life of the Soldier in and around Delville Wood}

South African historiography on the First World War concentrates mainly on the course of the war. Although some works deal with the daily experiences of the troops, no comprehensive study on the social history of the South African soldier on the frontlines during the First World War has appeared. Hopefully in future this shortcomming in South African military historiography will be remedied.

To understand the ordeals suffered at Delville Wood

22 SANDFArchives: WOI DA, Box 5. War Diary, 3rd South African Infantry Regiment July 1916, Operations on the Somme. (Attached: Appendices 143-157), pp.31-32.

23 SANDFArchives: WOI DA, Box 5, War Diary, 4th South African Regiment July 1916. Operations on the Somme, dated 31 July 1916, p.7; Ibid., War Diary, South African Infantry Brigade Headquarters July 1916, Operations on the Somme: Despatch No III by Brigadier General H.T. Lukin Commanding 1st S.A. Infantry Brigade, Frevillers, dated 14 August 1916, Casualties in Longueval and Delville Wood 14-20 July 1916; SANDF Archives: WOI DA. Box 3, War Diary \& Appendices, 1 Regt SAI July 1916, 1St Battalion, South African Infantry, dated 1 August 1916, p.7

24 R. Cornwell, "Delville Wood", Militaria 7(2), 1977, p.54.

25 C.J. Nöthling. Suid-Afrika in die Eerste Wereldoorlog, pp.48-52,79; The War Office, Statistics of the Military Effort of the British Empire during the Great War, 1914-1920, pp.237,756. 
better it is imperative to narrate the day to day experiences and activities of the South African soldiers.

\section{Dress and Equipment}

The kit of the South African soldier at Delville Wood weighed between 26,3 kilograms (58 pounds) and 36,3 kilograms ( 80 pounds). This included weapons (rifle, bayonet, shrapnel helmet, two tube helmets, ammunition, bombs, smoke candles [discharged smoke which concealed the movement of troops], grenades), an overcoat, a haversack (filled with rations, personal extras, a knife, oil tin, cap comforter), waterproof sheet, waterbottle, field dressing, iodine and various tools for the digging of trenches (entrenching tools, sandbags, a pick, a shovel, wirecutters, wire) and in case of a gas attack, a gas mask. The weight of the kit made life difficult for the soldier especially if he had to climb over the parapets during an assault on the enemy trenches. The weather during the assault on Longueval and Delville Wood was foul and everything was covered in mud. Subsequently the rain made movement more difficult as the ground became soggy and slippery. This further hampered the movements of the soldiers who were weighed down by their heavy gear. The rain and wet ground had a further disadvantage because the soles of their boots became drenched and soft. This caused great discomfort to the soldier. ${ }^{26}$

\section{Rations}

The soldiers' diet consisted of bullybeef, "dog biscuits", preserved meat, jam and oxo. Sardines were also very popular and were considered something of a delicacy. Liquid rations consisted of water and sometimes rum or tea. Each platoon received two cans of water. This was kept in waterbottles which the soldiers carried with them. Tobacco was also included in the soldiers' rations. ${ }^{27}$

Some troops were instructed to serve as couriers or runners and had to bring food and ammunition to the troops in the frontline. Before the Battle of
Delville Wood a few members of 3 SAI Regiment carried supplies to the unit's headquarters from where runners took it to the frontline troops. ${ }^{28}$ These couriers were exposed to enemy fire and shelling and many became casualties. On 16 July Lieutenant Somerset (probably Lieutenant Francis Somerset) of 3 SAI Regiment bravely disregarded the dangerous situation in the wood by carrying rations, water and letters to his men on the frontline. ${ }^{29}$

During the battle it was often impossible to deliver rations to the troops in the frontline. When their emergency rations (which were kept in their haversacks) ran out, they had to improvise. Four Privates in 1 South African Medical Corps (SAMC) who were carrying wounded men from Longueval to Bernafay Wood during the battle, kept their stomachs full by eating bits of biscuits which they found lying alongside dead soldiers. Private Arthur $\mathrm{H}$. Betteridge of 4 SAI Regiment writes that during the worst of the fighting on 18 July, the South Africans supplemented their food rations by collecting food, like bullybeef and dog biscuits, from their fallen comrades' haversacks. ${ }^{30}$ Private John A. Lawson of 3 SAI Regiment states that on the same day, 18 July, a fellow soldier named Breytenbach collected the food and water from dead soldiers and gave it to his comrades. ${ }^{31}$

The troops who were relieved in Delville Wood had the privilege of a hot meal consisting of boiled eggs and a cup of hot tea from the field kitchen. Tea was very popular. It was brewed in Delville Wood during the fighting and sometimes given to the wounded troops and those suffering from shellshock. Sometimes the soldiers received rum to keep them warm. ${ }^{32}$

\section{A Soldier's "Working Day" in and around Delville Wood}

Apart from the actual fighting, the South African soldier had other duties to perform during the Delville Wood battle.

Immediately after the objective was gained in

26. A.H. Betteridge, Combat in and over Delvilie Wood, vol 1, pp.23,31,37,40,44; SANDF Archives: Archive Group: World War One Diaries (hereafter WOI D), Box 8, 4th Regiment SAI. Papers on Trainıng 1916-1917, Instructions for the organization and training of formations and units of the 9th (Scottish) Division for the attack, Appendix A, B and D, dated 7 March 1916 ; SANDF Archives: WOI D, Box 7, 1st SAl Bde vol 3b, Brigade Major's Correspondence 1916-1917, File 47/4 (Gas), No X 4/1341/2, Gas Appendix A. 1, Notes on the employment of gas and smoke in the attack. B. Staff Arrangements for a gas and smoke attack, dated 11 August 1916; The story of Delville Wood told in letters from the front, p.18.

27 SANDF Archives: WOI D. Box 5, SA Infantry, Narratives and Reports for the year 1916 vol II, SA Infantry. Papers dealing with dumps, stores and supplies 1916, File 47/26/21/5, Headquarters, 1 st Infantry Brigade S.A.O.E.F. dated 5 July 1916.9 th Division, S.A.A. and Stores taken over from the 21st and 89th Brigades, giving Map references of Dumps, in accordance with your Q.C. 150, dated 4 July 1916, p.1: G.G.J. Lawrence, "Echoes of War 1915-1918 (Part 2)", Militaria 8(2), 1978, p.46; A.H. Betteridge, Combat in and over Delville Wood, vol 1, p.51: G.W. Warwick. We band of brothers: Reminiscences from the 1st S.A. Infantry Brigade in the 1914-1918 War, p.71.

28 E. Solomon, Potchefstroom to Delville Wood, pp.61-62,65.

J.A. Lawson, Memories of Delville Wood, p. 6.

A.H. Betteridge, Combat in and over Delville Wood, vol 1, pp.6,44,45,49,51; The story of Delville Wood, pp.28-29

J.A. Lawson, Memories of Delville Wood, p. 13

E. Solomon, Potchefstroom to Delville Wood, p.66; A.H. Betteridge, Cornbat in and over Delville Wood, vol 1, pp.32,45: The story of Delville Wood, pp. 26,44 . 
Delville Wood on 15 July 1916, the soldiers had to dig rifle pits to provide cover against the German counter attacks. These rifle pits were connected to form a trench with strong points at salients. The trench was later deepened to minimize the effect of shrapnel. The soldiers dug these trenches with entrenching tools which looked like fire shovels. The digging was considerably hampered by the roots and branches of trees and by enemy fire. Private Geoffrey G.J. Lawrence states that his company (C Coy 1 SAl Regiment) struggled from the night of 15 July to the early morning of 16 July to dig their trenches because the tree roots made digging very difficult. Lance-Corporal Ernest Solomon (A Coy 3 SAI Regiment) and his comrades had to lay on their stomachs while digging trenches because of the constant enemy shell and rifle fire. After this had been done the South Africans had to dig supporting trenches in Princes and Buchanan Streets. A trench was also dug in Strand Street. Lastly a strong point was dug about 137 meters (150 yards) north-east of the junction of Princes and Buchanan Streets. ${ }^{33}$ These trenches were the life-line of the South Africans in Delville Wood and without them they would have surely suffered more casualties.
Troops who were on "rest" duty and who were not fighting in the frontline, were used as "runners". As stated earlier these runners had to carry ammunition, tools, food and instructions to the frontline. These carrying parties were also known as "fatigue parties". Private Arthur H. Betteridge of 4 SAI Regiment tells us that the casualties suffered by these troops were sometimes greater than the casualties suffered by the troops in the frontline.$^{34}$ On 14 July Private Geoffrey G.J. Lawrence was sent on a fatigue party. This party had to take mortar shells from Longueval to a battery on the fringe of Delville Wood: "Our route took us through broken-down houses and streets where many of our dead were lying. At one corner we dodged around, quickly stepped over two dead men, and round the next shelter before the snipers could get us" ${ }^{35}$ This party made it safely back to their trenches. By 18 July all the telephone lines running to the front line were destroyed. Therefore all messages had to be delivered by a "runner" or messenger. ${ }^{36}$

Some troops went on bombing parties. A South African soldier Private Clive Canning (A Coy 4 SAI Regiment) recalls in a letter to his mother dated 24

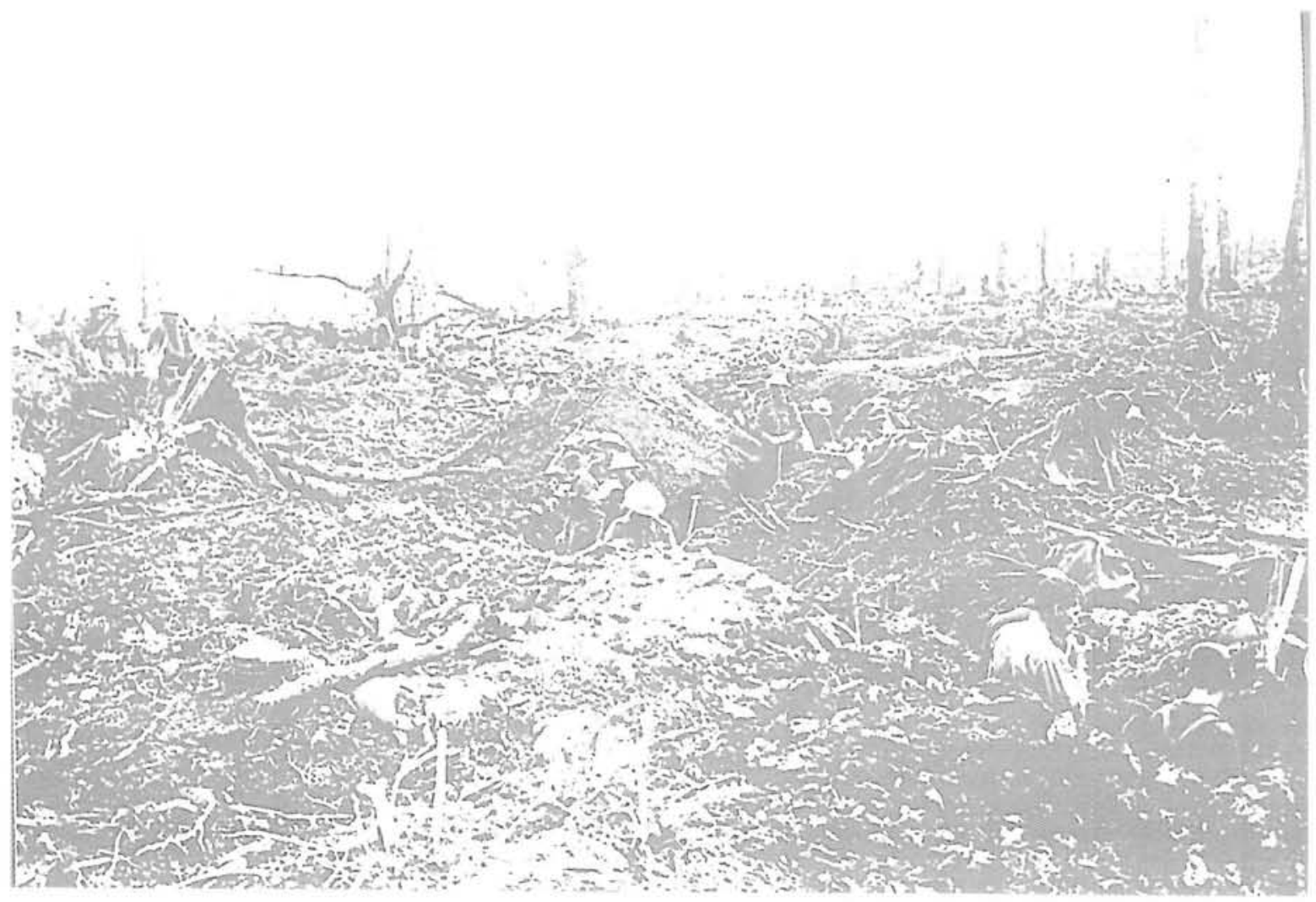

\section{A battered trench in Delville Wood}

33 SANDF Archives: WOI D, Box 7, 1st SAI Bde vol 3b. Brigade Major's Correspondence 1916-1917, File 47/10 (Somme), Conference of Unit Commanders of the SA Brigade with the Brigadier General Commanding the Brigade, Lessons to be learned from the recent operations, dated 31 July 1916; A.H. Betteridge, Combat in and over Delville Wood, vol 1, pp.42,43,47; G. G.J. Lawrence, "Echoes of War", Militaria 8(2), 1978, p.46: E. Solomon, Potchefstroom to Delville Wood, p.63.

${ }^{34}$ A.H. Betteridge, Combat in and over Delville Wood, vol 1, p. 24; The story of Delville Wood, p. 19.

35 G.G.J. Lawrence, "Echoes of War", Militaria 8(2), 1978, p.46.

36 A.H. Betteridge, Combat in and over Delville Wood, vol 1, p.49 
July 1916, how exciting it was bombing the Germans in Delville Wood: "We used to go out on our own, bomb the Allemande for about an hour, and then skedaddle back to our own trench, if we had one". ${ }^{37}$ Second Lieutenant F.S. English of 1 SAI Regiment and Private F.E. Dromgoole were both bombing the Germans on Sunday 16 July. Dromgoole was wounded after his bombing party had been "dishing out bombs to the Huns" ${ }^{38}$ Lieutenant English's endeavours enabled the sentries of 1 SAI Regiment to keep scouting without being shot at. ${ }^{39}$

The wounded had to be cared for as well. On 13 July the South African Bearer Division (stretcherbearers who evacuated the injured) was ordered to retire to dug-outs at West Peronne, Talus Boise, Cambridge Copse, Train Alley and Alt Trench. Orders were given that the wounded had to be evacuated from Collecting Posts to Dressing Stations (first aid posts) at Tallus Boise, Maricourt and Bernafay Wood. Horse-drawn ambulance wagons were also used to transport "sitting up cases" (soldiers who were not very badly wounded but could not walk) between Maricourt, West Peronne and Billon Farm. ${ }^{40}$

Only seriously wounded soldiers were treated at advanced dressing stations. Some of these stations were very near the action, as was the one near the edge of Longueval Village. Major Power, a Scottish Medical Officer, set up another station at the edge of Delville Wood and was constantly under fire. Less seriously wounded troops, the "walking wounded", were treated at medical clearing stations further away from the frontline. From there they were taken to dressing stations in the rear and finally to Field Hospitals. Some troops who received a "Blighty" (a serious wound) were sent to England to recover. ${ }^{41}$

The South African Medical Corps (SAMC) was responsible for caring for the wounded. Lance-Corporal Arthur McLauchlin of 1 SA Field Ambulance recalls in a letter dated 28 July 1916 that he was "doing nothing else but carrying wounded day and night " during the battle. His whole body was scratched by shrapnel. ${ }^{42}$ On occasion regular soldiers had to evacuate the wounded. On 18 July, 3 SAI Regiment had no stretcher-bearers left due to casualties. Lieutenant Colonel Dawson sent 16 men of 1 SAI Regiment to act as bearers for 3 SAI Regiment in the wood. ${ }^{43}$ For the "walking wounded" it often was a harrowing experience struggling to reach the dressing station. Private Will Peggs of 1 SAI Regiment, who had been wounded in the neck, was buried twice by falling debris on his way to the dressing station. He writes that: "Trees were falling all round us, likewise shells" and he felt "as though the whole German artillery were trying their best to blot me out." He concludes: "... that was hell to me, and it lasted for half an hour, until I arrived at the dressing station". ${ }^{44}$

A macabre task was the removal of the bodies of dead comrades from the trenches. Private Lawson and his mates in D Coy 3 SAI Regiment removed their dead on 17 July and temporarily layed them out in shell-holes before burying them. ${ }^{45}$

The conditions under which the South Africans had to perform these life-saving tasks were very poor.

\section{The Scars of Delville Wood}

During the First World War soldiers were subjected to very trying conditions. Hugh McManners writes as follow: "There was no room for sentiment or humanitarian considerations. The regiments had to hold the line as fodder for the artillery, or plod forward in ponderous offensives as the high-rolling General Staff gambled in their attempts to break the stalemate" ${ }^{46}$ This attitude of the General Staff contributed to the casualties suffered during the Somme offensive which started on 1 July 1916 and of which Delville Wood formed a part. During the first hour the British suffered 30000 casualties. This figure rose to 58000 at the end of the day. At the close of the Somme offensive during mid-November the number of casualties stood at $500000 .{ }^{47}$

Delville Wood is no exception when it comes to

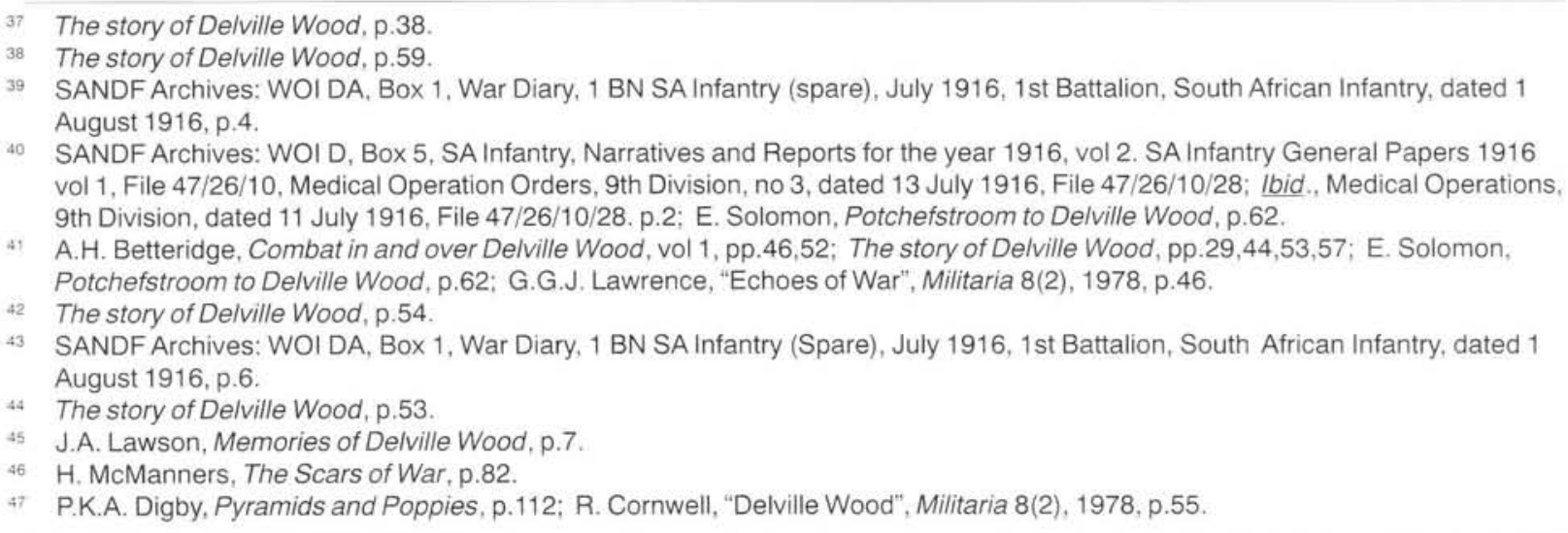

40 SANDF Archives: WOI D, Box 5, SA Infantry, Narratives and Reports for the year 1916, vol 2. SA Infantry General Papers 1916 vol 1, File 47/26/10, Medical Operation Orders, 9th Division, no 3, dated 13 July 1916, File 47/26/10/28; Ibid., Medical Operations, 9th Division, dated 11 July 1916, File 47/26/10/28. p.2; E. Solomon, Potchefstroom to Delville Wood, p.62,

4. A.H. Betteridge, Combat in and over Delville Wood, vol 1, pp.46,52; The story of Delville Wood, pp.29,44,53,57; E. Solomon, Potchefstroom to Delville Wood, p.62; G.G.J. Lawrence, "Echoes of War", Militaria 8(2), 1978, p.46.

The story of Delville Wood, p.54.

43 SANDF Archives: WOI DA, Box 1, War Diary, 1 BN SA Infantry (Spare), July 1916, 1 st Battalion, South African Infantry, dated 1 August 1916, p.6.

The story of Delville Wood, p. 53

J.A. Lawson, Memories of Delville Wood, p.7

H. McManners, The Scars of War, p.82.

P.K.A. Digby, Pyramids and Poppies, p.112; R. Cornwell, "Delville Wood", Militaria 8(2), 1978, p.55. 


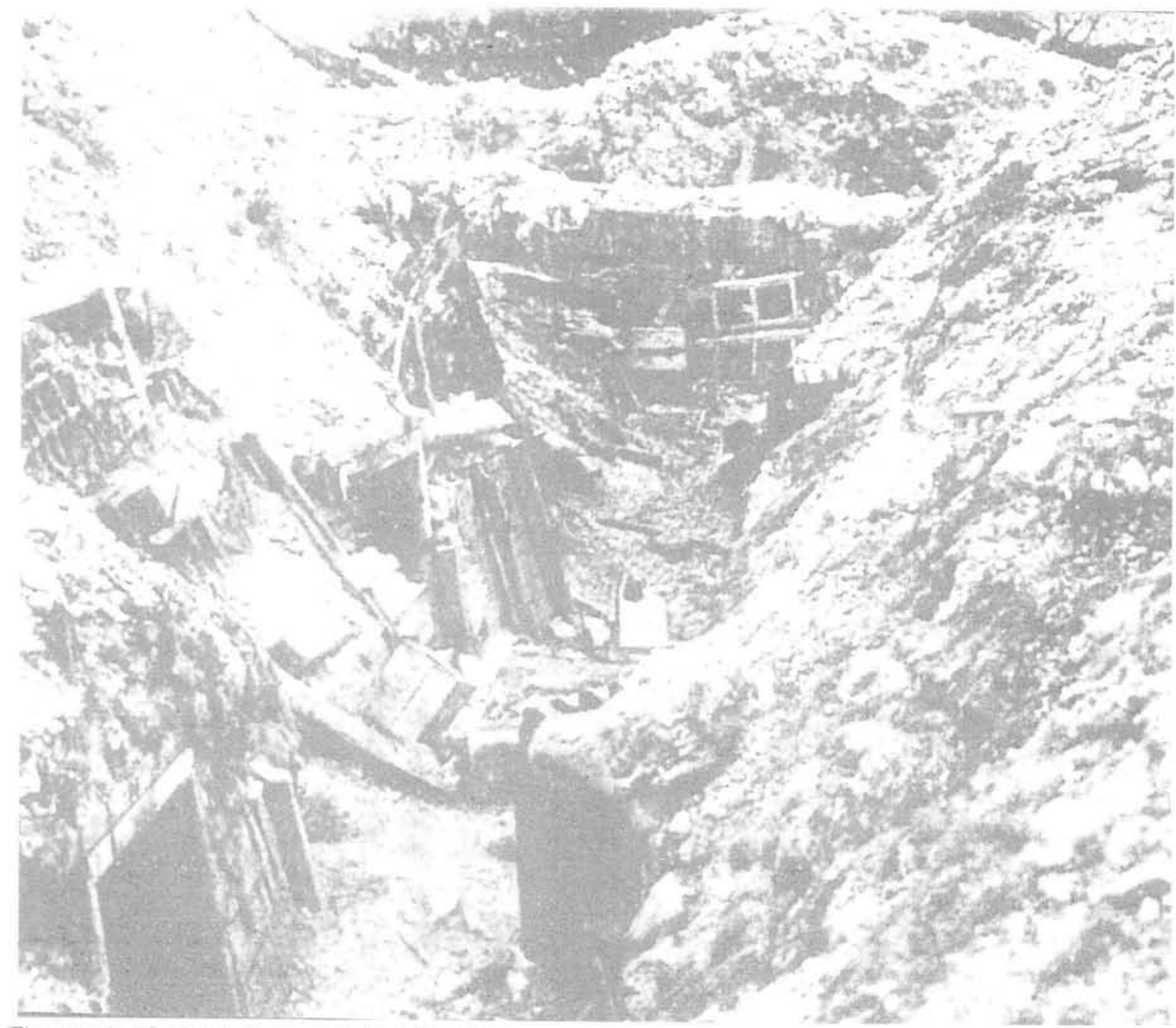

The scars of war. A dug-out in Delville Wood

SANDF Archives, 851.274

utter desolation. In the following extracts soldiers describe their privations in Delville Wood and surroundings

Corporal Hermann Bloom of 2 SAI Regiment gives a good description of the desolation in the wood: "When we went into the wood the growth was so dense you could hardly see ten yards in front of you, but before long there was neither a bough nor a leaf lett; the bare trees stood out riddled with lead, and the wood a mass of dead and wounded - it was awful! " 48

Private J. Simpson of 4 SAI Regiment describes what he saw when he entered the wood: "Here things were terribly confusing, for fighting was going on there at the time, and no one seemed to know just what direction to fire, and fellows in trenches in the centre of the wood did not know which direction from which to expect an attack" 49 The destructive force of the artillery fire in Delville
Wood is emphasized by Sergeant W.H. Johnston of 1 SAI Regiment: "Our bombardment had blown everything to bits. I am not exaggerating when I say that the whole place was full of big holes all next to one another. The trenches had been battered out of shape". ${ }^{50}$ Private Ivan McCusker of 3 SAl Regiment describes the scene at Longueval Village near Delville Wood. He states that on 15 July not a single wall was standing in this village and he adds: "The shells had fallen so thickly that the shell holes overlapped to such an extent that we had to walk through them, there being no part of the ground that had not been rent asunder". He further adds that Longueval "was battered almost as much as Montauban, but the dead were still lying thick in it; some men, battered out of all semblance of man by a huge bursting shell, lying in grotesque attitudes, probably some yards from their legs or arms". "Private Chas E. Long (3 SAI Regiment) who was one of the men of Lieutenant Colonel Thackeray's group who held out until the end 
states that the South Africans were "attacked on three sides every day and night, and bombarded with scores of guns - about 300 - for $131 / 2$ hours the last ten hours most severely. Shells fell amongst us like an African hailstorm, and still we stood it ". 52

The already trying situation in the wood was worsened by the rain. Constant rain made movement more difficult and it posed a health risk as well. A soldier could get trench feet. Because of the constant wetness of the feet a soldier ran the risk of losing his toes because they sometimes nearly rotted off. ${ }^{53}$ "All this time it was pouring with rain, and I was wet through and covered with mud from head to foot ". ${ }^{54}$ This was written by Private Ronald Rawbone (1 SAI Regiment) in a letter to his father. The earlier mentioned private in 1 SA Field Ambulance (SAMC) states that it rained nearly incessantly and the shell craters were filled with water. $\mathrm{He}$ further states that "these were mostly half-full of water, and we were constantly falling into them". ${ }^{55}$ This happened on the road between Bernafay Wood and Longueval. Lance-Corporal Solomon (3 SAI Regiment) further emphasizes the fact that the rain made life very difficult in Delville Wood: "Our boots, strong as they were, could not withstand the pressure of water and mud; waterproof sheets protected only our shoulders, and the other parts of our bodies received the rain and became soaked through". ${ }^{56}$ An officer gives the following account: "... from the 4th to the 20th officers and men had neither blankets nor greatcoats; it rained at least every other day, and one never got a decent sleep". ${ }^{57}$

But the rain could not inflict the wounds which were the scourge of every soldier's living day. These wounds not only indicate physical but also emotional wounds. Physical scars were inflicted by shrapnel, machine-gun fire, rifle fire and gas poisoning. Emotional and psychological scars were inflicted by the constant presence of death, exhaustion and the emotional trauma which goes hand in hand with shell-shock and gas poisoning.

Numerous physical wounds were inflicted during the fight for Delville Wood. Lance-Corporal Solomon of 3 SAl Regiment states that his Regiment suffered many casualties on 15 July. One of the casualties was Captain E.V. Vivian (3 SAI Regi- ment). Solomon further adds that: "One man who had joined us at Celestine Wood with a draft was cut clean in half by a shell and one disappeared and was not heard of again. Whether he was buried or blown to pieces was never found out ". 58 "Whizz bangs" or high velocity shells were Private Lawrence's and a sergeant's undoing in Delville Wood. At 15:00 on 16 July the Germans bombarded C Coy (1 SAI Regiment) with these high velocity shells: "They burst in pairs just above our heads. We heard them exploding on their way up over us, past and then coming down again. On the second trip up, the two burst just above our trench with a crash. A piece came flying back past my ear and drawn up legs and struck in my right thigh. There was a scream from the next little trench as a poor sergeant was badly smashed up and mortally wounded by the same shell " ${ }^{59}$ Fortunately Lawrence survived this ordeal.

Private Clive Canning was twice hit by shrapnel. During the second incident a piece of shrapnel hit the book which he carried in his left-hand breast pocket; the shrapnel was parried. His pocket book saved his life. But he was not so lucky before this incident when a piece of shrapnel did wound him. But he saw some humour in the incident: "... I tried to protect Government property by endeavouring to stop a piece of shrapnel from going through my boot, with the result that it not only went through the boot but through my foot also". ${ }^{60}$ Private Nicholas Vlok of 2 SAI Regiment was a former Boer officer from Bloemfontein who served in the AngloBoer War. On 15 July he was wounded in the knee and back. He supported himself by sitting up against a tree. A German came up to him and after cursing at Vlok in Dutch (Afrikaans, the language of the Afrikaners is similar to Dutch) shot him in the head. Vlok's helmet was blown off but fortunately the bullet missed his head. The German thinking he had killed the South African, left. ${ }^{61}$ On the same day Corporal Hermann Bloom was hit in the leg in Delville Wood by a bullet from a machine-gun: "I dropped and lay face down, as though dead" ${ }^{62}$ Some soldiers suffered side-effects from wounds received. Private Hallam Sampson (3 SAI Regiment) suffered blood-poisoning after shrapnel hit him in the legs. ${ }^{63}$ The previously mentioned Private A.H. Betteridge was wounded on 18 July, the day the fighting in

\footnotetext{
The story of Delville Wood, pp.54-55 pp.31, 37, 40; The story of Delville Wood, pp.15, 30, 44.

The story of Delville Wood, p.26.

The story of Delville Wood, p.30.

E. Solomon, Potchefstroom to Delville Wood, p.67

The story of Delville Wood, p.15.

E. Solomon, Potchefstroom to Delville Wood, pp.64-65.

G.G.J. Lawrence, "Echoes of War", Militaria 8(2), 1978, pp.46-47.

The story of Delville Wood, p.37.

I. Uys, Rollcall, p.60.

The story of Delville Wood, p.44.

The story of Delville Wood, p.52.
}

M. Brown, The Imperial War Museum Book of the First World War, p.55; A.H. Betteridge, Combat in and over Delville Wood, vol 1 , 
Delville Wood reached a climax. Betteridge had to take a cook named "Geordie" into Delville Wood to deliver a message: "We ducked into a large shellhole and as I got up to go on, I felt as though a mule had kicked me and fell to the ground. I had been hit in the thigh by the nosecap of a 5.9" shell. I don't remember hearing the burst of the shell that hit me. A four inch hole appeared in my left thigh, breaking my leg" ${ }^{64}$ Geordie dressed Betteridge's wound with a bandage. The former was later on killed but Betteridge managed to reach safety. ${ }^{65}$

The German snipers who penetrated behind the South African lines in Delville Wood, inflicted demoralizing casualties. The above-mentioned Corporal Bloom states that "their snipers were potting at us when we came in, and I may say lots of wounded chaps and stretcher-bearers were killed in this way". ${ }^{66}$ Private Herbert Farrow (1 SAI Regiment) had a lucky escape in Delville Wood on 15 July. A sniper's bullet which hit his safety razor in his jacket pocket, glanced off the razor. The latter saved his life. But he didn't walk away from the incident unscathed. The bullet ripped a piece of flesh from his thigh just below the hip bone. ${ }^{67}$ Private F.E. Dromgoole was hit on 16 July by sniper fire. He was caught in the arm by an explosive bullet which splintered the bone. Later on the same day he was wounded in the head by a bullet and again in the back and left shoulder by a piece of shrapnel. ${ }^{68}$

German gas shells and tear shells had an effect on the battle as well. These gas attacks led to considerable suffering. The Germans used two kinds of gas shells during the battle, the Lachrymatory (tear shells) and Asphyxiating Shells. Lachrymatory Gas primarily affected the eyes and caused considerable irritation. Asphyxiating Gas was a strong irritant and primarily affected the lungs. It did not always affect the eyes. It was more volatile and less dense than Lachrymatory Gas and dissipated rapidly. A soldier likened the smell of the gas to that of sulphurous matches. ${ }^{69}$

Sergeant J.W. Adams (4 SAI Regiment) who was wounded in Delville Wood on 16 July mentions the discomfort and pain caused by the use of tear-gas by the Germans: "Before attacking they sent over tear shells, which blind your eyes with tears, tears streaming down your face. The pain is awful ".70 Private John A. Lawson writes the following concerning a German tear-shell attack in Delville Wood on 18 July: "Three-fifths of their shells were tearshells. We shed tears copiously". He further states that "Our gas-masks became stuffy and suffocating, and had to be discarded". Lawson describes tear-gas as "the product of the ingenuity of perverted human brain, fertile in the invention of the vile implements of scientific warfare". ${ }^{71}$ Private Kenneth Earp (4 SAl Regiment) who was wounded in Delville Wood on 19 July writes in a letter to his parents that he was affected by gas in Montauban. He describes what happened: "The experience was an awful one. One's throat got sore and water came out of the eyes as if one had had ammonia thrown in them" ${ }^{72}$ The letter of Private J. Simpson dated 24 July 1916 confirms this. Simpson was part of a group of South African soldiers who were moving up to Delville Wood. On the way they were bombarded with tear shells: "These shells are nonpoisonous, but irritate the eyes terribly, causing tears to flow; also burn the nose and throat " ${ }^{73}$

Soldiers also suffered from the debilitating effects of Asphyxiating Gas. Arthur C. Stanley of the Machine Gun Section was affected by this gas in the Delville Wood battle and describes the feeling: "The pain is not bad, only a tired feeling and suffocation, alternating with violent fits of coughing that do not remove the obstruction". ${ }^{74}$ In a report by the Brigade's Signal Section on Asphyxiating Gas poisoning at Montauban on the night of 17/18 July 1916 , it is mentioned that six men of this section were affected by gas poisoning. These soldiers suffered from "catarrh in the head and throat, fits of coughing, tightness and pains in the chest, general lassitude, and pains throughout the body resembling those caused by influenza" ${ }^{75}$ The gas caused the soldiers to gasp for air. The officer who compiled the report writes: "I have personally suffered considerably since from excessive catarrh, and irritation of the throat and bronchial tubes". ${ }^{76}$

\footnotetext{
A.H. Betteridge, Combat in and over Delville Wood, vol 1, p.50.

A.H. Betteridge, Combat in and over Delville Wood, vol 1, pp.49-51.

The story of Delville Wood, p.44.

The story of Delville Wood, p. 52 .

The story of Delville Wood, p.59.

SANDF Archives: WOI D. Box 7, 1st SAI Bde vol 3b, Brigade Major's Correspondence 1916-1917, File 47/4 (Gas), Notes on German Shells [S.S.453] General Staff (Intelligence), General Headquarters, July 1916; Ibid., File 47/4 (Gas), Reports by transport and other officers on Asphyxiating Gas shells at Montauban on the night of July 17/18th. pp.2,11.

The story of Delville Wood, p.32.

J.A. Lawson, Memories of Delville Wood, p.13

The story of Delville Wood, p.36.

The story of Delville Wood, p.41

The story of Delville Wood, p.49.

SANDF Archives: WOI D. Box 7, 1st SAI Bde vol 3b, Brigade Major's Correspondence 1916-1917, File 47/4 (Gas), Reports by transport and other officers on Asphyxiating Gas shells at Montauban on the night of July 17/18th, p.2.

76 SANDF Archives: WOI D, Box 7, 1st SAI Bde vol 3b. Brigade Major's Correspondence 1916-1917, File 47/4 (Gas), Reports by transport and other officers on Asphyxiating Gas shells at Montauban on the night of July 17/18th, p.2.
} 
The transport sections, transporting ammunition and rations to the frontline soldiers, also suffered from gas poisoning. An officer of A Coy $1 \mathrm{SAI} R e-$ giment who was in charge of a transport team who was transporting rations on the road between Montauban and Longueval was bombed with Asphyxiating shells. The gas caused these soldiers considerable discomfort. The soldiers started to "cough violently for several minutes". One of the transport drivers vomited and the Lieutenant had difficulty in breathing. Transport teams of 3 and 4 SAI Regiments were also affected. They suffered the same symptoms as the above-mentioned soldiers. Animals were not immune to gas attacks and the transport horses of these Regiments suffered as well. ${ }^{77}$

Numerous emotional and psychological scars were also sustained during the fighting. Many soldiers suffered from shell-shock. Today this condition is called Post-traumatic Stress Disorder. The emotional, psychological and physical strain of war cause this mental and nervous disorder in soldiers. Post-traumatic Stress Disorder has many features. This includes fatigue (neurasthenia), nervousness, instability, depression, cognitive difficulties (such as poor concentration), emotional numbing to life experiences, nightmares through which the trauma is re-experienced, anxiety and listlessness. ${ }^{78}$ The soldiers described this condition as shell-shock. The above-mentioned J. Simpson states that "A fellow with shell-shock is just like a frightened child, trembles violently, weeps, and requires someone to take charge of him". ${ }^{79}$ George W. Warwick a Lance-Corporal in 4 SAI Regiment describes a soldier who suffered from shell-shock in Bernafay Wood: " $L /$ Cpl. J... [sic] was lying in front of me and his leg trembled. I urged him to pull himself together, not realising that he was suffering from shell-shock. His legs continued to tremble, so I flung myself on his legs" ${ }^{80}$ This incident took place on 10 July. This soldier cried and trembled but refused to leave the wood. Private W.D.D. Ryan (1 SAI Regiment) was first buried by a shell and then blown into the air. $\mathrm{He}$ was unconscious for approximately six hours and was treated for shell-shock at Fulham Military Hospital. ${ }^{81}$ Private Betteridge was also affected by the constant shell fire in the Wood: "... we simply carried on, half-dazed by the interminable shell fire, doing just what we had been trained to do". As can be seen the shell fire affected this soldier's nervous condition. ${ }^{82}$

Fatigue (neurasthenia) was a common occurrence because the South Africans in and around Delville Wood had to fight day and night. Private Betteridge states that: "Lack of sleep, after hours of continuous action was beginning to take its toll ".83 $\mathrm{He}$ further states that during 18 July the remaining troops in the wood were "half stupid from fatigue and lack of sleep". ${ }^{84}$ Private Roy Makepeace (1 SAI Regiment) was exhausted physically and mentally after three charges against the Germans and Private Thomas Herbert Holiday (1 SAI Regiment) states that "my nerves gave way from exhaustion" and he had to be assisted to the dressing station after he had been wounded on 17 July. ${ }^{85}$ Private Lawson writes that on the night of 17 July the South Africans of D Coy 3 SAI Regiment were "tried beyond all endurance". The troops were "Deaf to the roar of hundreds of guns and explosions of shells all around". The soldiers were so exhausted that most fell asleep. ${ }^{86}$ On 18 July Lawson and his comrades were "spent in body and at last worn out in spirit" ${ }^{87}$

Major D. MacLeod, who commanded 4 SAI Regiment in the wood, was also traumatised. He narrated his ordeal in Delville Wood after he had been wounded in a letter dated 21 August 1916 and which was addressed to General Lukin. "I was quite dazed and after going a few yards towards Col Thackrey's [sic] trench I had to lie down and Come [sic] to myself again, when passing through the village assisted by some wounded men". ${ }^{88}$

The heavy casualties suffered meant that many soldiers lost their comrades and friends. These troops were replaced by strangers, which further increased the emotional and psychological strain on them.

In these terrible conditions Hugh McManners states that the only option left to the soldiers "was the camaraderie of his own small group of soldiers the infantry section, the artillery gun crew ". ${ }^{89}$ This

\footnotetext{
7 SANDF Archives: WOI D, Box 7, 1st SAI Bde vol 3b, Brigade Major's Correspondence 1916-1917, File 47/4 (Gas), Reports by transport and other officers on Asphyxiating Gas shells at Montauban on the night of July 17/18th, pp.1-2, 4, 10-11.

78 H. McManners, The Scars of War, pp.91-93;

H.I. Kaplan \& B.J. Sadock a.o. (eds.), Synopsis of Psychiatry: Behavioral Sciences Clinical Psychiatry, 6th. ed., pp.409-410.

The story of Delville Wood, p.39.

G.W. Warwick, We band of brothers, p.71.

The story of Delville Wood, p.35.

A.H. Betteridge, Combat in and over Delville Wood, vol 1, p. 45.

A.H. Betteridge, Combat in and over Delville Wood, vol 1, p. 45.

A.H. Betteridge, Combat in and over Delville Wood, vol 1, pp.48-49.

The story of Delville Wood, pp.50,57.

J.A. Lawson, Memories of Delville Wood, p.12.

J.A. Lawson, Memories of Delville Wood, p.14.

в8 SANDF Archives: WOI D, Box 7, 1st SAI Bde vol 3b, Brigade Major's Correspondence 1916-1917, File 47/6 (Lewis Gun), Letter: Major D. MacLeod-Brigadier General H.T. Lukin dated 21 August 1916, London Whitechapel.

39. HCManners, The Scars of War, p.79.
} 
camaraderie in Delville Wood prompted many soldiers to acts of bravery. On 16 July Lieutenant Arthur W. Craig (1 SAI Regiment) was lying in the open after being wounded. Privates William $\mathrm{F}$. Faulds, George F. Baker and Alexander Estment (all three of 1 SAI Regiment) risked their lives and carried Lieutenant Craig back to safety. Private Faulds of 1 SAI Regiment was the first South African of the Brigade to be awarded the coveted Victoria Cross. ${ }^{90}$ Captain Claude Browne (4 SAI Regiment) was twice saved by the commander of $3 \mathrm{SAI}$ Regiment, Lieutenant Colonel Thackeray. On 18 July Browne was lying out in the open where he was exposed to sniper fire. Thackeray pulled him to safety. On the following day Browne was again lying in the open on a mound of earth at the back of a trench and was covered with earth after duds (shells) fell next to him. Thackeray again pulled him to safety. Thackeray was wounded six times and knocked over three times by artillery fire and bombs during the South Africans' last stand in Delville Wood. ${ }^{91}$ The streatcher-bearers who were mentioned above also risked their lives in carrying their wounded comrades to safety under constant rifle and shell fire.

\section{Conclusion}

On 10 October 1926 a ceremony was held in Delville Wood to unveil the South African National Memorial. Although the memorial was erected in Delville Wood, it was not only to commemorate the dead at Delville Wood but it was dedicated to all fallen South Africans. The inscription on the memorial reads as follows: "To the immortal dead from South Africa who, at the call of Duty, made the Great Sacrifice on the battlefields of Africa, Asia and Europe, and on the Sea, this Memorial is dedicated in proud and grateful recognition by their countrymen". Even the then Prime Minister of the Union of South Africa, J.B.M. Hertzog, who had been strongly opposed to South Africa's participation in the Great War, on this occassion stated his admiration for the South Africans who fell while fighting in the Great War: "The part played in that drama by these our Dead, will ever be an inspiration to us who appreciate their unflinching spirit of self-sacrifice at the call of duty". ${ }^{92}$

On 11 November 1986 the Delville Wood Commemorative Museum with beautiful glass and bronze panels, was inaugurated by the then State President, P.W. Botha. ${ }^{93}$ It is a dedication to the South Africans who fell not only in Delville Wood and the Great War, but in the Second World War (1939-1945) and Korean War (1950-1953) as well.

\section{Bibliography}

\section{PRIMARY SOURCES}

\section{DOCUMENTATION SERVICE DIRECTORATE [SANDF ARCHIVES], PRETORIA}

\section{WORLD WAR ONE DIARIES}

WOI D: Box 5, SA Infantry, Narratives and Reports for the year 1916 vol II, SA Infantry General Papers 1916 vol. I, File 47/26/10.

WOI D: Box 5, SA Infantry, Narratives and Reports for the year 1916 vol II, SA Infantry Papers dealing with dumps, stores and supplies 1916, File 47/26/ 21.

WOI D: Box 7, 1st SAI Bde vol 3b, Brigade Major's Correspondence 1916-1917, File 47/4 (Gas).

WOI D: Box 7, 1st SAI Bde vol 3b, Brigade Major's Correspondence 1916-1917, File 47/6 (Lewis Gun).

WOI D: Box 7, 1st SAI Bde vol 3b, Brigade Major's Correspondence 1916-1917, File 47/10 (Somme).

WOI D: Box 8, 4th Regiment SAI. Papers on Training 1916-1917.

\section{WORLD WAR ONE DIARIES AND APPENDICES}

WOI DA: War Diary, Box 1, War Diary, 1 BN SA Infantry (spare), July 1916, 1st Battalion, South African Infantry, dated 1 August 1916.

WOI DA: Box 3, War Diary \& Appendices, 1 Regt SAI July 1916, 1st Battalion, South African Infantry, dated 1 August 1916.

WOI DA: Box 5, War Diary, South African Infantry Brigade Headquarters July 1916, Operations on the Somme.

WOI DA: Box 5, War Diary, 1st South African Infantry Regiment July 1916, Operations on the Somme.

WOI DA: Box 5, War Diary, 2nd South African Infantry Regiment July 1916, Operations on the Somme.

WOI DA: Box 5, War Diary, 3rd South African Infantry Regiment July 1916, Operations on the Somme. (Attached: Appendices 143-157).

WOI DA: Box 5, War Diary, 4th South African Regiment July 1916, Operations on the Somme, dated 31 July 1916.

All Photos are published with the kind permission of the Documentation Service Directorate (SANDF Archives) in Pretoria.

\section{SECONDARY SOURCES}

CORNWELL, R., "Delville Wood: The South Africans in France, April-July 1916". Militaria 7(2), 1977.

90 P.K.A. Digby, Pyramids and Poppies, p.131; SANDFArchives: WOI DA, Box 5, War Diary, 1st South African Infantry Regiment July 1916, Operations on the Somme, dated 1 August 1916.

P.K.A. Digby, Pyramids and Poppies, pp.131-132.

SANDF Archives: Pamphlet Collection, Box 108, nr. 2923: The Delville Wood Memorial Book, pp.6,12-14.

SANDF Archives: Pamphlet Collection, Box 108, nr. 5789; The South African Delville Wood Commemorative Museum. 
LAWRENCE, G.G.J., "Echoes of War 1915-1918 (Part 2)". Militaria 8(2), 1978.

BETTERIDGE, A.H., Combat in and over Delville Wood, vol. 1. Unpublished Manuscript.

BROWN, M., The Imperial War Museum Book of the First World War. London, Sidgwick \& Jackson, 1993.

BROWN, M., The Imperial War Museum Book of the Western Front. London, Sidgwick \& Son, 1993.

BUCHAN, J., The History of the South African Forces in France. London, Thomas Nelson \& Sons LTD., 1920.

DIGBY, P.K.A., Pyramids and Poppies: The 1st SA Infantry Brigade in Libya, France and Flanders 1915-1919. Rivonia, Ashanti Publishing (Pty) Ltd, 1993.

EWING, J., The History of the 9th (Scottish) Division, 1914-1919. London, John Murray, 1921.

KAPLAN, H.I. \& B.J. SADOCK a.o. (eds.), Synopsis of Psychiatry: Behavioral Sciences Clinical Psychiatry, 6th. ed. London, Williams \& Wilkins, 1991.

LAWSON, J.A., Memories of Delville Wood, South Africa's Great Battle. Cape Town, T. Maskew Miller, 1918.

MCMANNERS, H., The Scars of War. London, Harper
Collins Publishers, 1994

NÖTHLING, C.J., Suid-Afrika in die Eerste Wêreldoorlog (1914-1918). Silverton, Suid-Afrikaanse MilitêrHistoriese Konsultante, 1994.

SOLOMON, E., Potchefstroom to Delville Wood (with the 3rd South African Infantry): Together with some experiences as a Prisoner of War in Germany. Johannesburg, Football \& Sports Publishers, nd.

The story of Delville Wood told in letters from the front. Cape Town, Cape Times Limited, nd.

The War Office, Statistics of the Military Effort of the British Empire during the Great War, 1914-1920. London, His Majesty's Stationery Office, 1922.

UYS, I., Rollcall: The Delville Wood Story. Johannesburg, Uys Publishers, 1991.

WARWICK, G.W., We band of brothers: Reminiscences from the 1st S.A. Infantry Brigade in the 1914-1918 War. Cape Town, Howard Timmins, 1962.

Documentation Service Directorate (SANDF Archives): Pamphlet Collection, Box 108, WOI: Libië, lerse rebelle, lugoorlog ens. 